\title{
AEROMAGNE'TIC, BOUGUER GRAVITY, AND GENERAIIZED GEOLOGIC MAPS OF THE CENTRAL PART OF THE LITTLE BELT MOUNTAINS, MONTANA By
}

M. D. Kleinkopf, I. J. Witkind, and W. R. Keefer

\author{
GEOPHYSICAL INVESTIGATIONS \\ MAP GP-837
}

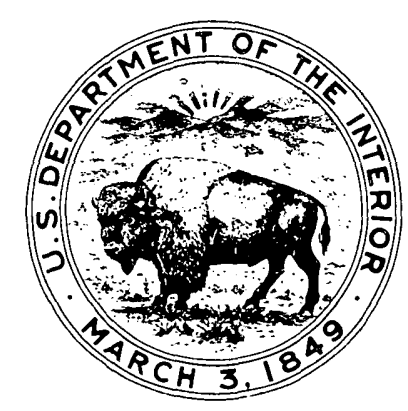




\section{AEROMAGNETIC, BOUGUER GRAVITY, AND GENERALIZED GEOLOGIC MAPS OF THE CENTRAL PART OF THE LITTLE BELT MOUNTAINS, MONTANA By \\ M. D. Kleinkopf, I. J. Witkind, and W. R. Keefer}

\section{INTRODUCTION}

Aeromagnetic and gravity surveys were made in a north-trending strip across the central part of the Little Belt Mountains, a laccolithic complex which rises above the plains of central Montana. The work was done primarily to determine the configuration of buried intrusions which deform sedimentary, metasedimentary, and crystalline metamorphic rocks, and which locally have yielded significant amounts of silver, lead, and zinc (Weed, 1899b; Schafer, 1935; Witkind and others, 1970).

The Little Belts are one of several laccolithic and volcanic mountain groups scattered through central Montana, including the Highwood, Little Rocky, and Bearpaw Mountains to the north, the Moccasin, Judith, and Big Snowy Mountains to the east, and the Castle and Crazy Mountains to the south (index map). The mountain groups appear to be structurally independent of each other.

The area of study is about 400 square miles and extends from lat $46^{\circ} 45^{\prime} \mathrm{N}$. to lat $47^{\circ} 15^{\prime} \mathrm{N}$., and from long $110^{\circ} 30^{\prime} \mathrm{W}$. to long $110^{\circ} 45^{\prime} \mathrm{W}$. It covers the Barker and Neihart 15-minute quadrangles.

Kleinkopf is responsible for interpretation of the geophysical data, which have been released previously (U.S. Geological Survey, 1969; - Witkind and others, 1970). Witkind mapped the geology in the Barker quadrangle and Keefer mapped the geology in the western half of the Neihart quadrangle. The geologic data shown in the eastern half of the Neihart quadrangle are from an earlier map by Weed (1899b).

\section{GENERAL GEOLOGY}

The Little Belt Mountains were first studied in reconnaissance by Weed $(1899 \mathrm{a}, 1899 \mathrm{~b}, 1900)$ and Pirsson (1900). Since then various other geologists have reported on specific geologic subjects (Schafer, 1935; Deiss, 1936; Lochman and Duncan, 1944; Catanzaro and Kulp, 1964).

Both the Barker and the western half of the Neihart quadrangles have recently been mapped in detail, and several maps (Keefer, 1969; Witkind, 1969a) and reports (Witkind, 1965, 1969b, 1970; Witkind and others, 1970) have been published.

These studies indicate that the core of the Little Belt Mountains consists of Precambrian crystalline metamorphic rocks, chiefly hornblende-biotite gneiss, that were intruded at various times during the Precambriàn by both felsic and mafic rocks.
The major felsic intrusion now appears as red augen gneiss; the major mafic intrusion is the Pinto Diorite, a distinctive mottled rock in which clusters of hornblende grains are scattered through a matrix of greenish-white feldspar. Amphibolite and pegmatite dikes of Precambrian age cut all the crystallines. Most of the crystalline rocks are the products of medium- to high-grade regional metamorphism and are probably best grouped in the amphibolite facies.

These older Precambrian crystalline rocks are truncated by the younger upper Precambrian metasedimentary rocks of the Belt Supergroup.

The north flank of the core is overlain unconformably by Paleozoic and Mesozoic sedimentary units, totalling 4,800 feet in thickness, which range in age from Middle Cambrian (Flathead Sandstone) to Early Cretaceous (Kootenai Formation). Along the south flank the crystalline rocks are separated from the overlying sedimentary rocks by a wedge of metasedimentary units of the Precambrian Belt Supergroup which thickens southward with the addition of still younger units.

At some time during the early Tertiary the complex of Precambrian crystalline rocks was intruded and raised by a compound felsic pluton. It seems likely that the height of the mountains is attributable in large part to this uplift. How high the core was raised is unknown; steep to near-vertical dips of those sedimentary strata which encircle it imply that the amount of uplift may have been several thousand feet.

All rocks have been warped, broken, and locally metamorphosed by early Tertiary intrusions of diverse size and shape composed of felsic, intermediate, and mafic rocks. These include stocks, laccoliths, sills, dikes, and other plutons of indeterminate form. The height of individual mountains is directly related to one or another of these intrusions. Thus, each upwarp-dome or anticline-reflects in a gross way the shape and size of the underlying pluton; and each downwarp-basin or syncline-is the result of the downwarp of the strata between adjacent intrusions.

Most of the intrusions are formed of either felsic or intermediate rocks; the mafic rocks constitute only a small amount of the total volume of igneous rock emplaced. Porphyries of rhyolite and granite are the major felsic rock types; quartz latite porphyry 
is the major intermediate rock type; and minette, kersantite, vogesite, and shonkinite are the major mafic rock types.

Cross-cutting relations among the igneous bodies, as well as preliminary $\mathrm{K}-\mathrm{Ar}$ radiometric data ( $\mathrm{R}$. F. Marvin, oral commun., 1970), suggest that there have been two episodes of felsic intrusion separated by an episode of intermediate intrusion. The mafic rocks apparently were emplaced synchronously with the younger felsic rocks.

In the Barker quadrangle (Witkind, 1965), various of the laccoliths are arranged radially about a stock. The stock and at least one of the laccoliths are cut by dikes of felsic and mafic rocks and by composite dikes (mafic margins flanking felsic cores).

\section{COLLECTION AND REDUCTION OF GEOPHYSICAL DATA}

About 400 miles of traverses were flown in a northsouth direction at spacings of 1 mile and at a barometric elevation of 9,000 feet above sea level. The magnetic measurements were made with a continuously recording ASQ-10 fluxgate magnetometer in a tail boom on the Geological Survey's Convair aircraft. Position control was from topographic maps, and the flight paths were recovered using a gyrostablized 35-mm continuous-strip camera and Doppler navigation (Evenden and others, 1967). Base lines, which were closed on themselves, were flown normal to traverse lines for correction of diurnal and instrumental drift. The total intensity data are referenced to a proton-magnetometer reading of the absolute value of the earth's magnetic intensity. The gradient of the earth's normal field has not been removed from the data.

Gravity data for 300 stations were obtained in the study area by means of a gravity meter with a scale constant of about $0.5 \mathrm{mgal}$ per dial division. Station elevations were obtained from bench marks es- tablished by the U.S. Coast and Geodetic Survey and the U.S. Agriculture Department, and from spot elevations shown on $7 \frac{1}{2-}$ - and 15 -minute topographic maps. The gravity measurements were adjusted to the absolute datum of the Wollard airport base, Station WA 124, at Great Falls, Mont. (Wollard and Rose, 1963, p. 99). The data were reduced to complete Bouguer gravity values using an assumed rock density of $2.67 \mathrm{~g} / \mathrm{cm}^{3}$. Terrain corrections were made through the $\mathrm{H}$ zone of Hammer (1939) with hand templates and out to $167 \mathrm{~km}$ by means of a digital computer (Plouff, 1966). The accuracy of the gravity map is estimated to be about $1 \mathrm{mgal}$. The regional gravity gradient decreases to the south across the map at a rate slightly less than 1 mgal per mile.

\section{INTERPRETATION OF THE GEOPHYSICAL DATA}

The interpretation of the geophysical data was largely qualitative, with studies concentrated on interrelationships of the magnetic, gravity, and geologic features shown on the map. The geologic cross section with observed magnetic and gravity profiles $\left(A-A^{\prime}\right)$ depicts interpretations of the subsurface along the western side of the study area. The results of laboratory analyses of rock samples (table 1) collected from outcrops, and measurements of anomaly amplitudes, provide a basis for estimating magnetic susceptibility and density contrasts.

Density and magnetic susceptibility -measurements in table 1 show-significant contrasts between major rock types that are important to the interpretations. The Precambrian Pinto Diorite and the gneiss complex have average densities of 2.90 and $2.68 \mathrm{~g} / \mathrm{cm}^{3}$, respectively, whereas the Tertiary porphyry rocks have an average of $2.53 \mathrm{~g} / \mathrm{cm}^{3}$. For magnetic susceptibility, the Pinto Diorite has a very high average of $49.1 \times 10^{-4} \mathrm{emu} / \mathrm{cm}^{3}$ (electromagnetic units per
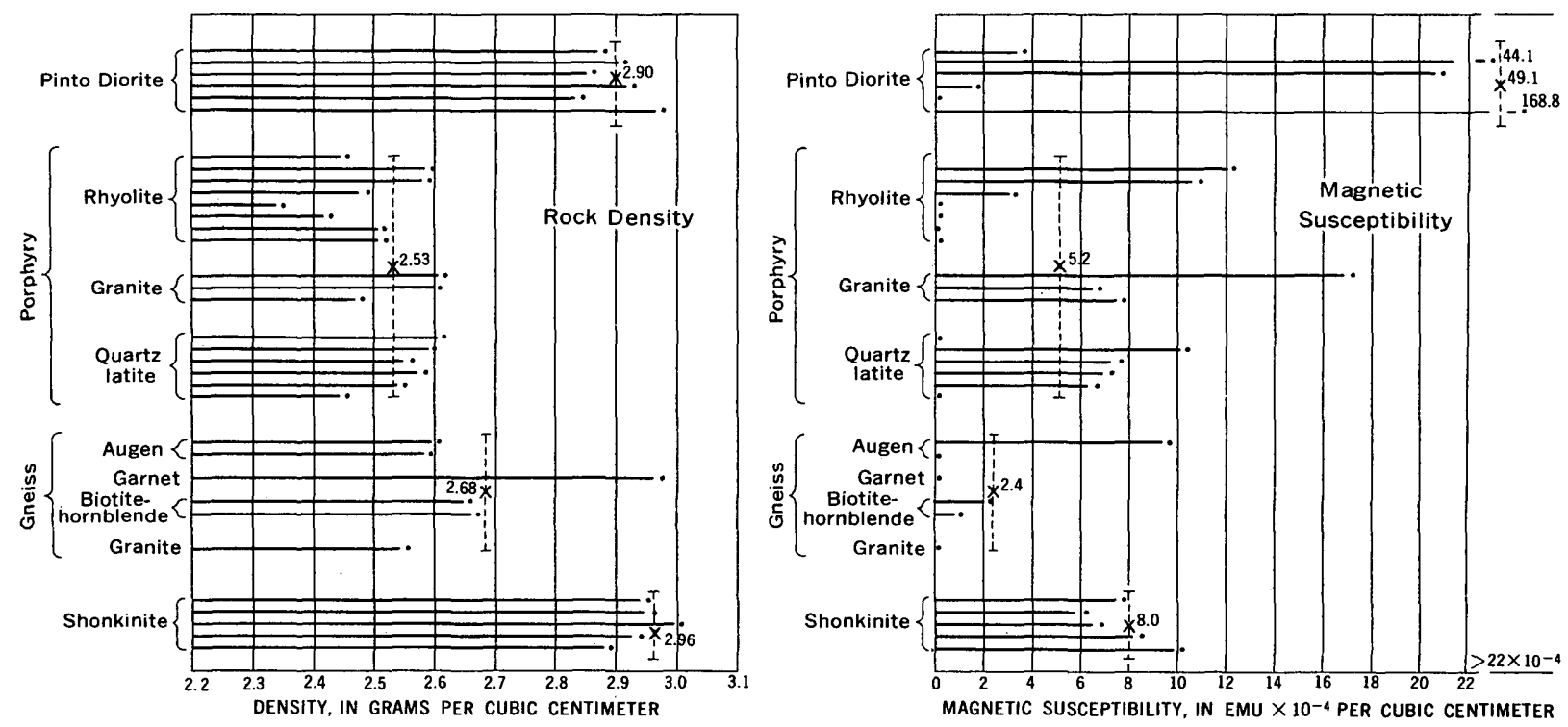
cubic centimeter), whereas the gneiss has a low average of $2.4 \times 10^{-4} \mathrm{emu} / \mathrm{cm}^{3}$. The porphyry rocks average $5.2 \times 10^{-4} \mathrm{emu} / \mathrm{cm}^{3}$.

Many magnetic and gravity features are similar in position, trend, and configuration, although the degree of correlation of local anomalies varies considerably. The magnetic pattern consists primarily of two distinct types of features-broad positive anomalies of elliptical plan (defined roughly by the 4,300-gamma contour) located in the northwestern and central parts of the area, and a series of local closures which are superimposed on major features in the central and southern parts of the area. The gravity field is dominated by a negative anomaly which grossly corresponds to the broad positive magnetic anomaly of the central area. The local closures and nosings of the gravity contours are attributed to minor lithologic variations in the crystalline complex. The density of rhyolite porphyry collected from outcrops along Carpenter Creek (1) ${ }^{1}$ averages $0.15 \mathrm{~g} / \mathrm{cm}^{3}$ less than that of the surrounding hornblende-biotite gneiss (table 1), which is the predominant Precambrian rock type. The negative gravity anomaly at Clendennin Mountain (2) and Clendennin-Peterson anticline suggests that the porphyry of Clendennin Mountain extends northeast of the outcrop beneath Paleozoic (Cambrian) sedimentary rocks. This is consistent with dips measured in the exposed strata. The gravity contours suggest that the porphyry of Clendennin Mountain is separated from the large mass of concealed rhyolite porphyry (3) to the southwest. The magnetic data also strongly suggest a separation as shown by the high gradient zone along the 4,300-gamma contour. The magnetic data further suggest abnormal magnetic polarities in the rocks of this area. No information on remanent magnetization is available.

The three local positive magnetic anomalies $(4,5$, 6) with values exceeding 4,800 gammas, which are superimposed on the broad positive anomaly of the central area, are attributed to Pinto Diorite. Two of the anomalies $(4,5)$ along the west edge of the map and shown on section $A-A^{\prime}$ correlate with outcrops of Pinto Diorite. The positive anomaly that reaches a high of 5,086 gammas near the east end of Poverty Ridge (6) suggests near-surface Pinto Diorite. The steep magnetic gradient (7) shown in the section just north of Belt Creek appears also to be caused by Pinto Diorite. Just south of Sawmill Creek (8), also along the line of section, the steep magnetic gradient may be caused either by Tertiary igneous rock of intermediate composition (quartz latite porphyry) or concealed Pinto Diorite. Positive gravity anomalies also correlate with the outcrops and suspected subcrop of Pinto Diorite.

The combined magnetic contribution of porphy-

'Localities discussed in the text are identified on the maps by a circled number. ritic rocks and Pinto Diorite probably accounts for the 300 -gamma positive anomaly that extends across the central part of the area. The relative volumes of porphyry and diorite are unknown, but laboratory results show positive magnetic susceptibility contrasts for both diorite and porphyry relative to the gneiss complex (table 1). In particular, studies of the relationship of magnetic patterns to porphyry outcrop show a good correlation between the quartz latite porphyry and positive magnetic anomalies. Examples are at Butcherknife (9), Taylor (10), and Barker Mountains (11). The magnetic susceptibility of such rocks was found to average about $7 \times 10^{-4}$ $\mathrm{emu} / \mathrm{cm}^{3}$.

The broad 300-gamma positive magnetic anomaly located in the central part of the study area is complicated by a north-northwesterly trend in the magnetic data approximately along the 4,400-gamma contour, which extends from near Big Baldy Mountain (12) to Barker Mountain (11). Outcrops and concentrations of high-intensity magnetic values indicate that the Pinto Diorite is limited to the west side of the trend. In addition, there are discontinuous northnorthwesterly alinements in the gravity data along the magnetic feature, particularly in the area just west of Big Baldy Mountain. Also along the feature is the deep magnetic low (13) centered about 1 mile northwest of Big Baldy Mountain. This may be caused by alteration in the quartz latite porphyry which has resulted in destruction of magnetite. Another possible expression of alteration effects is the somewhat smaller negative anomaly (14) nearby that centers only about 1 mile east-northeast of the Silver Dyke mine (15).

A negative gravity anomaly (16) about 3 miles southeast of Neihart village (7) may represent a subsurface extension of the low-density porphyritic rocks exposed locally along Snow Creek (1). An alternative interpretation is that the anomaly reflects the sharp contrast between the low-density Belt rocks and the surrounding higher density Cambrian carbonate formations. To the south, a positive magnetic trend (17) correlates in part with high topography which extends southeastward from Kings Hill Pass (18) in terrane composed largely of outcropping Cambrian and Devonian sedimentary rocks. This is also a structural high-probably bowed up by underlying intrusions.

In the northwest part of the study area, a prominent positive magnetic anomaly (19) of over 400 gammas in amplitude correlates with Limestone Butte, a domed area in which Mississippian limestone is exposed. Limestone Butte is believed to be underlain by a laccolith composed of quartz porphyry (section $A-A^{\prime}$ ). Preliminary model studies show that to approximate the shape and amplitude of the observed anomaly, the laccolith, as shown in the section, would need to be 4,000 feet thick with a feeder stock 7,000 feet in diameter that extends 
indefinitely deep. A somewhat higher magnetic susceptibility is required for the porphyry $\left(20 \times 10^{-4}\right.$ $\mathrm{emu} / \mathrm{cm}^{3}$ ) than measured in the laboratory for other porphyry samples $\left(7 \times 10^{-4} \mathrm{emu} / \mathrm{cm}^{3}\right)$. The east-west elongation of the anomaly is attributed to concentrations of dikes and sills radiating from the lower part of the laccolith. The gravity contours, although poorly controlled, suggest a high-density mass in the subsurface which would correspond to the source of the magnetic anomaly.

In the southeast part of the study area several local positive magnetic anomalies dominate the pattern. At Yogo Peak (20), an anomaly of nearly 1,000 gammas is attributed to a combination of monzonite and shonkinite as mapped by Weed (1899b). The shonkinite has a magnetic susceptibility of $8.0 \times 10^{-4} \mathrm{emu} / \mathrm{cm}^{3}$. The amplitude of the Yogo Peak anomaly is much greater than amplitudes over the more magnetic Pinto Diorite outcrops apparently because the magnetometer was nearly 2,000 feet closer to the source. Northeast of Yogo Peak, at the east edge of the study area (21), the syenite mapped by Weed (1899b) is magnetically high, although syenite outcrops in two nearby areas show little magnetic expression-2 miles to the northwest at Silver Gulch (22) and $6^{1 / 2}$ miles south near Middle Fork Ranch (23). The two positive anomalies at Coyote Peak (24) and Hell Creek (25) are on magnetic trend with the Yogo Peak anomaly and may represent buried monzonite and (or) shonkinite rock. The sources of the anomalies just southeast of Grendah Mountain (26) and southeast at Sand Point (27) are believed to be intrusives, at least in part. The Sand Point anomaly may be related to the positive trend extending east-southeast from Porphyry Peak (28) and Kings Hill Pass (18).

\section{REFERENCES}

Catanzaro, E. J., and Kulp, J. L., 1964, Discordant zircons from the Little Belt (Montana), Beartooth (Montana), and Santa Catalina (Arizona) Mountains: Geochim. et Cosmochim. Acta, v. 28, no. 1, p. 87-124.

Diess, Charles, 1936, Revision of type Cambrian formations and sections of Montana and Yellowstone National Park: Geol. Soc. America Bull., v. 47 , no. 8 , p. $1257-1342$.

Evenden, G. I., Frischknecht, F. C., and Meuschke, J. L., 1967, Digital recording and processing of aeromagnetic data: U.S. Geol. Survey Prof. Paper 575-D, p. D79-D84.

Hammer, Sigmund, 1939, Terrain corrections for gravimeter stations: Geophysics, v. 4, p. 184-194.
Keefer, W. R., 1969, Preliminary geologic map of the Neihart ( $7 \frac{1}{2}$ minute) quadrangle, Cascade and Judith Basin Counties, Montana: U.S. Geol. Survey open-file report.

Lochman, Christina, and Duncan, Donald, 1944, Early upper Cambrian faunas of central Montana: Geol. Soc. America Spec. Paper 54.

Pirsson, L. V., 1900, Petrography of the igneous rocks of the Little Belt Mountains, Montana: U.S. Geol. Survey 20th Ann. Rept., Pt. 3, p. 463-581.

Plouff, Donald, 1966, Digital terrain corrections based on geographic coordinates [abs.]: Geophysics, v. 31, no. 6, p. 1208.

Schafer, P. A., 1935, Geology and ore deposits of the Neihart Mining District, Cascade County, Montana: Montana Bur. Mines and Geology Mem. 13.

U.S. Geological Survey, 1969, Aeromagnetic map of the Barker and Neihart quadrangles, Judith Basin, Cascade, and Meagher Counties, Montana: U.S. Geol. Survey open-file report.

Weed, W. H., 1899a, Fort Benton, Montana: U.S. Geol. Survey Geol. Atlas, Folio 55. $1899 \mathrm{~b}$, Little Belt Mountains, Montana: U.S. Geol. Survey Geol. A tlas, Folio 56. 1900 , Geology of the Little Belt Mountains, Montana, with notes on the mineral deposits of the Neihart, Yogo, and other districts: U.S. Geol. Survey Prof. Paper 453.

Witkind, I. J., 1965, Relation of laccolithic intrusion to faulting in the northern part of the Barker quadrangle, Little Belt Mountains, Montana: U.S. Geol. Survey Prof. Paper 525-C, p. C20-C24.

$1969 \mathrm{a}$, Preliminary geologic map of the Barker ( $7 \frac{1}{2}$ minute) quadrangle, Judith Basin and Cascade Counties, Montana: U.S. Geol. Survey open-file report.

$1969 \mathrm{~b}$, Clinopyroxenes from acidic, intermediate, and basic rocks, Little Belt Mountains, Montana: Am. Mineralogist, v. 54, p. 1118-1138. 1970, Composite dikes in the Little Belt Mountains, central Montana, in Geological Survey Research 1970: U.S. Geol. Survey Prof. Paper 700-C, p. C82-C88.

1971, Geologic map of the Barker quadrangle, Cascade and Judith Basin Counties, Montana: U.S. Geol. Survey Geol. Quad. Map GQ-898.

Witkind, I. J., Kleinkopf, M. D., and Keefer, W. R., 1970, Geologic and gravity evidence for a buried pluton, Little Belt Mountains, central Montana, in Geological Survey Research 1970: U.S. Geol. Survey Prof. Paper 700-B, p. B63-B65.

Woollard, G. P., and Rose, J. C., 1963, International gravity measurements: Wisconsin Univ. Geophys. and Polar Research Center, $518 \mathrm{p}$. 